\title{
Redmond and Carson: Bloodshed, Borders and the Union State
}

Redmond et Carson : l'affrontement, les frontières et l'Union

Alvin Jackson

\section{(2) OpenEdition}

Journals

\section{Electronic version}

URL: http://journals.openedition.org/rfcb/3806

DOI: $10.4000 /$ rfcb.3806

ISSN: 2429-4373

\section{Publisher}

CRECIB - Centre de recherche et d'études en civilisation britannique

\section{Electronic reference}

Alvin Jackson, «Redmond and Carson: Bloodshed, Borders and the Union State », Revue Française de Civilisation Britannique [Online], XXIV-2 | 2019, Online since 19 June 2019, connection on 09 July 2019. URL : http://journals.openedition.org/rfcb/3806 ; DOI : 10.4000/rfcb.3806

This text was automatically generated on 9 July 2019.

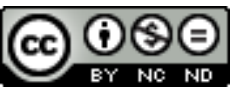

Revue française de civilisation britannique est mis à disposition selon les termes de la licence Creative Commons Attribution - Pas d'Utilisation Commerciale - Pas de Modification 4.0 International. 


\title{
Redmond and Carson: Bloodshed, Borders and the Union State
}

\author{
Redmond et Carson : l'affrontement, les frontières et l'Union
}

\author{
Alvin Jackson
}

\section{AUTHOR'S NOTE}

The text of this article is drawn from a discourse presented to the Royal Irish Academy on 6 March 2018, and introduced by the Taoiseach, Leo Varadkar TD. The themes of the article are developed at greater length in Alvin Jackson, Judging Redmond and Carson: comparative Irish lives (Dublin, Royal Irish Academy, 2018).

\section{Introduction}

1 These men were the two greatest Irish parliamentarians of their generation: they were perhaps the best-known Irishmen of the time. And their achievements - and their mistakes - lastingly shaped the political landscape of modern Ireland and indeed of the United Kingdom. Their careers say much about the working of the multi-national union state wherein they found themselves. Their careers, and in particular their role in the Irish and British Home Rule crisis of 1910-14, speak to other concerns which have a real contemporary resonance.

2 They were of course on the face of it political opposites: John Redmond was the leader of the Irish nationalist parliamentary party from February 1900 through to his death in March 1918; Edward Carson was the leader of the Irish unionists from 1910 through to 1921, when he became a Law Lord. And yet the parallels between the two are clear. They were of the same (mid-1850s) Irish generation. They were educated at the same university, Trinity College Dublin. They pursued the same profession (the law) in the same legal circuits. They sat together for 26 years in the one parliament. They were 
tireless political opponents, yes, but professed a friendship and mutual respect. One was a home rule nationalist, the other an Irish unionist; yet they shared some monarchical, imperial, federalist and indeed anti-suffragist sympathies. ${ }^{1}$

3 Contemporaries of all kinds - from the king to cartoonists - routinely linked them. Even their own families - Harry Carson (Edward's son) and Louis Redmond-Howard (John's nephew) - came together in presenting a number of bitter patricidal critiques of their elders (including a co-written one act melodrama in 1914). ${ }^{2}$ And yet the two protagonists of the Home Rule struggle have rarely been brought together analytically.

It is notable that where comparative biography of great political rivals is a common place elsewhere (there are, for example, the several joint lives of Disraeli and Gladstone, Wellington and Napoleon, Hitler and Stalin), comparative political biography and comparative political history are relatively underdeveloped genres within modern Irish historiography. This is perhaps because the kinds of connection which might be made (say) between constitutional nationalist and physical force separatist or - as in this case between nationalist and unionist cut across still acute political sensitivities.

5 It is also the case that the two "lives" have been separated out by the division of the island into two popular and opposing political narratives. "Partitionist history" within an Irish context can be defined partly as dealing with nationalists and unionists exclusively in their separate silos, and ignoring common political environments, the crossfertilisation of ideas - and cross-communication (however fractious).

\section{Why does all this particularly matter just now?}

6 The year 2018 brought the centenary of the death of John Redmond, with a surge of commemorative activity on the anniversary, 6 March, and the subsequent weeks. But the era of the third Home Rule bill, and the careers of Redmond and Carson, and the contexts to their activity, have much contemporary resonance for both Ireland and Britain.

This period of Home Rule, so dominated by Redmond and Carson, was one of unusually intense and concentrated political passion not just for Ireland but for Britain too - and it serves as a reminder that while the stability of the United Kingdom is often taken for granted, there has been a history of threatened conflagration and near melt-down. The tone and content of political discourse over Home Rule in 1910-14 bear some resemblance to those which have prevailed in Britain over Brexit. ${ }^{3}$ The period was one of intense and bitter passion, especially for Carson's Conservative allies - who were split over Britain's trading relationship with the wider world - and in particular over the issue of free trade. In seeking to "make [Edwardian] Britain great again" the Conservatives in 1912-14 turned to Irish unionists like Carson with a dangerous passion.

But the era not only defined issues and problems of lasting importance; it also threw up projected solutions which remain in play. There were different, hard and soft, versions of what constituted partition, for example (the partition envisioned in 1914 or 1916 was very different from that enacted in 1920-22). Many, including both Carson and Redmond, believed that a federal reform of the British constitution - still very much relevant as a possibility - might reconcile Irish nationalism to a reformed union or imperial state.

More generally, for some influential $21^{\text {st }}$ century Scots (such as the former First Minister, Alex Salmond) the struggle of Irish nationalists for Home Rule and independence has been a frequently cited inspiration. But, it was Charles Stewart Parnell - aggressive and 
charismatic - whose portrait Alex Salmond chose to display in his parliamentary office at Westminster, and not that of the more emollient and genteel John Redmond. ${ }^{4}$ In a sense, therefore, understanding Mr Salmond's choice of interior decor provides a pointer to some of the central themes of this essay.

\section{Formation and careers: relevance to the cultures of the Union state the $19^{\text {th }}$ and early $20^{\text {th }}$ centuries}

10 Redmond's parents were estranged. Carson was the favoured sibling in a relatively stable family environment. And (while this is not the place to unravel the intricacies of attachment theory) it is still likely that these circumstances were linked to Redmond's conspicuous lack of wide networks of friends and allies - as well as to Carson's indomitable self-confidence and theatrical braggadocio. ${ }^{5}$

Redmond was from the Catholic professional and landed classes and there was money in his family networks. Carson's family was arriviste: there are hints of a somewhat louche quality. Though Carson was a southern Irish Protestant, he was not a landed Protestant; and there is evidence to suggest that after his father's death the family were left in " straitened [financial] circumstances". ${ }^{6}$ In other words Redmond was materially secure, but personally insecure in terms of background; Carson (on the other hand) was well anchored in his family affections, but he felt materially threatened until the day he died, leaving in his will the modern equivalent of nearly $€ 10$ million.

Redmond and Carson were both lawyers, but here the similarity ended. Carson can be defined by his social and professional role as a lawyer in ways which don't apply to Redmond. Carson's success in the law courts generated leverage within a British parliament increasingly professional in its makeup and values - even with his enemies. Indeed Carson's legal career was reaching its peak at precisely the moment that Home Rule was returning to centre stage (in 1910): he defended George Archer-Shee, the “ Winslow boy" of Terence Rattigan's later (1946) drama, in early 1910. ${ }^{7}$

Recent history weighed heavily with each in terms of their outlook and strategies. Part of the problem with Redmond was the extent to which the legacy both of Charles Stewart Parnell and of the profound "split" within constitutional nationalism (1891-1900) after the latter's death weighed down upon him. This illuminates his own relentless concern for unity. But in some ways Redmond was loyal to the letter but not necessarily to the spirit of Parnellism. Carson (who was occasionally compared to Parnell by contemporaries) was clearly influenced by a particular historical reading of successive British governments' willingness to respond to Irish political mobilisation.

Finally, each of them was a compromise leader, and each was circumscribed by this. Each of them was in some ways marginal to the central concerns of the parties that they ended up leading - Redmond as a Parnellite in a largely anti-Parnellite united party, Carson as a southern unionist in a largely northern unionist movement. The resulting limits on Redmond's freedom of manoeuvre are well-known; but there was also a considerable distance between Carson's public certainties over the union and his much more circumspect private behaviour in 1910-14.

Each of the men worked with a particular set of personal legacies; but each also worked within, and was defined by, a particular type of political environment. One way of thinking about Redmond and Carson, and the social and political roles that they occupied, 
is to look at the structure of the state in which they operated. Those union states, like the UK, which emerged in the late $18^{\text {th }}$ and early $19^{\text {th }}$ centuries were often created in similar circumstances, against the backdrop of European warfare, and they shared some common characteristics. This is not the place to reflect at length about the conceptualisation of union, but a couple of fundamental points are worth highlighting.

The UK (like other united kingdoms) was of course an asymmetrical union - one overwhelmingly "predominant partner" (to use the language of Lord Rosebery) and several (like Ireland and Scotland) much smaller. It was also an imperfect or an incomplete union - in so far as distinctively Scottish or Irish institutions remained after 1707 and 1801.

Empire was conceptually relevant to these union states, in so far as they were not only often connected to overseas colonisation, but were sometimes founded upon forms of internal colonialism. ${ }^{8}$ The types of governance which they sustained and the kinds of political culture also overlapped with empire: in the Irish case there was a viceroy, favoured social and political classes through whom government was largely sustained, and complex or hybrid political cultures which were often pulled between the metropolitan power as well as local traditions. Partition (as in Bengal in 1905) was also an imperial stratagem which was ultimately applied to Ireland.

18 As the historian K.T. Hoppen has recently reminded us all, the politics of the Westminster elite through much of the period of union were characterised often by a relative ignorance of Ireland and of the union and by a relative lack of any lastingly coherent vision of union. This expressed itself in cyclical shifts between integrationist approaches to the government of Ireland and exceptionalist or even devolutionist approaches. ${ }^{9}$

19 Moreover, Irish politicians, whether nationalist or unionist, fought for attention, and then fought to educate or inform British ministers and party leaders. The corollary of this was the deepening of political division within Ireland itself, since the competing parties tended to look for external support and validation rather than internal reconciliation. But there was little of this pathology that was unique to Britain and Ireland: for example, Austrian politics in the later decades of the Dual Monarchy have been described (by Steven Beller) as an evermore "vertical hierarchical system - where the parties bargained with the government [...] rather than with each other [...]; the aim of the game was to put one over on the opponent rather than to come to a compromise with him." ${ }^{10}$ This - in essence - was the " system" in place in Ireland.

How does all of this relate to Redmond and Carson? Redmond and Carson had a low-key but persistent friendship from about 1890. But there was a striking absence in their political relationship: there is little to suggest that - despite all of the ties mentioned earlier - they had much direct negotiation with each other particularly when their British allies were not present. Each of them looked primarily to the British parties to represent their cause.

21 For each this carried an ongoing risk of dependency or clientelism - which in the past was only off-set by highly combative constitutional nationalist leaders such as Daniel O'Connell and Parnell - or through the studied defiance of the militant separatists enrolled within the Irish Republican Brotherhood (or Fenians). There were also (as we will see) clear distinctions between the ways in which Carson navigated the politics of the union parliament and government, and Redmond's ways.

Carson had a critical advantage - British Conservatism relied upon the union as a unifying mechanism since the party was otherwise still wrangling over tariff reform and 
free trade, and over its leadership in 1910-11. In addition the Conservatives' embroilment in Ulster obscures the fact that Carson had partly liberated himself from Westminster politics through the popular political mobilisation which had occurred in the north after 1911-12. The central irony of the period was of course that the strength of Redmondite nationalism hinged largely upon its position in the British parliament, while that of unionism now lay in Ireland itself.

Redmond's essential difficulty was that he was coping with a still fragile constitutional nationalist tradition (nominally - but only nominally - united after the internal conflagrations of the 1890s), and seeking to collaborate with a broadly united Liberalism which was sympathetic towards, but not passionate about Home Rule. Moreover, it was a Liberalism which believed that (as Asquith said in 1913) "the Nationalists without the support of the Liberal Party were powerless." 11

Redmond's relative weakness was expressed in terms either of lack of communication from Liberal ministers, debilitating partial affirmation, or broken promises (this was particularly clear in the negotiations of February/March 1914 and of June/July 1916). This relative weakness was also directly expressed in terms of discourse. His vocabulary and pitch (in dealing with ministers) were often, seemingly, those of a supplicant. He frequently deployed the language of "fair play." ${ }^{12}$ A characteristic motif of his correspondence was anxious petitioning: a characteristic tone, on the other hand, was offended gentility. Even Redmond himself recorded on occasion that he felt "really humiliated in having to run after them [British ministers] in the way I have done." ${ }^{13}$ All this was not a feature of Parnell's communication - nor, for that matter, of Carson's. A striking contrast between how the two men navigated the British establishment came with their respective meetings with Lord Kitchener on 6/7 August 1914: Carson responded to Kitchener's various threatening suggestions with a sarcastic "you're a damned fine fellow" and "I'd like to see you try"; while Redmond gently recorded that he had been "rather disquieted" by his parallel conversation with Kitchener. ${ }^{14}$ "Rather disquieted" and "I'd like to see you try" are an eloquent conjunction or introduction to their two styles.

Turning finally to wider contexts - most analyses of the survival or demise of union states or multinational empires of the $19^{\text {th }}$ century stress the role of monarchy and loyalty and its associated institutions (like the army) as critical binding agents and as engines of a supranational state identity (Oszkár Jászi, the Hungarian-born sociologist of the AustroHungarian empire, stressed the role of the Habsburgs as a key "centripetal" force, and more recent work by Pieter Judson and others has done likewise). ${ }^{15}$ Work on the Bernadotte monarchy in the United Kingdoms of Sweden-Norway points to a similar set of unifying functions. ${ }^{16}$ Both Redmond and Carson were primarily Irish in terms of their identity (indeed Carson was sometimes accused of stage-Irishness); but each acknowledged a supranational set of imperial and monarchical loyalties. Redmond's monarchism and imperialism and commitment to the British war effort are generally seen unflatteringly or uncomprehendingly in the context of either unionism or (by contrast) a purist republican separatism. But there is a case for understanding him partly by looking back to the O'Connellite tradition of nationalist "loyalty"; and also partly by looking sideways to a wider European phenomenon of nationality and state loyalty, brokered through the agency of the crown and its institutions.

Redmond's - and Carson's - fundamental characteristic was that they reflected the hybridity of Irish political culture under the union - the janus-faced looking to union or imperial as well as national themes. This again is only surprising if judged by the 
standards of an essentialist Britishness or Irishness - or judged from the standpoint of an uncompromisingly partitioned Ireland. And indeed, work on identity in other multinational union states conventionally emphasises the contingency and negotiability of identity - as well as its linkages and layers. ${ }^{17}$

\section{Bloodshed}

Violence, whether real or threatened, was also a common feature of Europe's united kingdoms of the $19^{\text {th }}$ century. This should scarcely surprise, since these supranational unions were being constructed at precisely the moment of mounting national sentiment across the continent. And each of the two careers poses questions about how essentially constitutional politicians operate in a society where there are strong cultures either celebrating or practising violent political resistance. A number of points may be highlighted in illuminating this theme.

To start with, a water-tight distinction between "constitutionalist" and "militant" in modern Irish history is generally hard to sustain. There is in fact some analytical value behind Seán Lemass' notion (applied to the newly founded Fianna Fáil party in 1926) of being "slightly constitutional." 18

Why did Redmond shift to a greater militancy in 1913-14, as the political crisis over Irish Home Rule developed? He did so firstly, of course, as a response to unionist mobilisation in the north of Ireland. But the question has also to be grasped in terms of his own longstanding relationship with physical force nationalism, and in particular with the Irish Republican Brotherhood (or Fenian movement). He had a strong sense of the history of national insurgency and was at the forefront of the centenary commemoration of the 1798 Rising. He built links with Fenians and Fenianism in the 1890s. The issue was not therefore that his relationship with the militants was ever absent. But Redmond's closest links with Fenianism had come in the 1890s - and by 1914 he had a conception of Fenianism which was both outmoded and incomplete.

Moreover, Redmond did not absolutely oppose political violence in principle; but he saw conditions in which the Irish might legitimately resort to arms. There are overlaps here with Catholic - Thomist and other - teaching on the notion of the just war. One aspect of his reasoning certainly related to the overwhelming strength of British firepower, the impracticality of any Irish assault - and the inevitability of bloody Irish defeat. ${ }^{19}$

Why was Redmond evidently so unimpressed by unionist militancy in 1912-14? This was essentially because he believed that he understood and shared their strategic calculations. In 1908 he wrote that "there are friends of ours who say that any violent action in Ireland will alienate support here [in Britain]. But the sounder view is that you have got, in some way or another, once more to impress the English mind that the Irish question is a real, urgent, one. ${ }^{20}$ In Redmond's view Carson's militants were bluffing in 1912-14 because like him they understood that tackling the military might of the British empire would produce a bloodbath; but he also "knew" that they were bluffing because he saw that they, like Irish nationalists, were primarily seeking to "impress the English mind" through their militant postures.

Why, then, did Carson shift to militancy in 1910-14? The answer to this rests partly again with "impressing the English mind". But unionist militancy came at the end of a long period of northern reorientation towards local organisation and initiative. ${ }^{21}$ 
Carson introduce the gun into Irish politics? He unquestionably helped to illegally introduce large numbers of guns into Ireland and its politics. There is certainly a case for saying that he introduced the gun into Redmondite politics. But of course he was not the first militant Irish politician, or the first to threaten the British government with armed insurgency. In the end the key point about Carson and militancy was not primarily that he was the first to introduce guns into Irish politics. It was rather that he was the first who deliberately wanted to be seen introducing guns into Irish politics. ${ }^{22}$

\section{Were Carson and Redmond the effective architects of the partition of the Ireland?}

Neither Carson nor of course Redmond invented partition as a concept, or even as a concept with an Irish application. It was in fact privately mooted with the first Home Rule bill in 1886, and had been given imperial applications before 1912 .

As is very well known, Carson was a driver of partition, while Redmond reluctantly acquiesced in an increasingly difficult range of partitionist proposals forced upon him by his Liberal allies. As is relatively well known, they were ultimately divided not by the principle of partition, which Redmond loathed, and Carson disliked, but by its practicalities and potential application: Carson sought ultimately the indefinite exclusion from Home Rule of the six counties which became Northern Ireland, while by 1916 Redmond was prepared to countenance a term-limited or otherwise clearly "temporary" exclusion.

But a number of under-explored issues are worth highlighting, especially perhaps given contemporary concerns. Part of the problem in dealing with partition in Irish history is that it is such a heavily freighted and teleological term; but the Brexit debates arising from the "backstop" over the Irish border have served to underline that there is - and has been - no single definition of either partition or its associated frontiers. Home Rule, as defined in 1914, did not give an Irish parliament any untrammelled right to disrupt free trade. Therefore, opting out of Home Rule did not create an economic or necessarily a " hard" political border any more than such existed between Northern Ireland and Britain in the years of devolution. It was not eastern Ulster opting out of Home Rule which created the form of partition which we have been living with in Ireland for a century; it was rather eastern Ulster opting out of the revolution.

In some ways partition was an example of the law of unintended consequences in politics. For Carson partition was a tactic which became a compromise which was reimagined as a fundamental goal: the unity of Ireland was pragmatically replaced in 1914-16 by the idea of a soft border and then almost accidentally in 1920-21 by a hard border. Carson began as an all-Ireland unionist who long knew that the concentrated industrial wealth and unionism of the north-east posed a problem for Liberal Home Rulers. Only from about the autumn of 1913 onwards did he look seriously at partition as a meaningful compromise position. ${ }^{23}$ And only from 1920 did he publicly and retrospectively define partition as the immutable objective of northern unionism.

For Redmond partition was an anathema and remained an anathema. He and his senior lieutenant, John Dillon, had a particularly well-organised northern support base through the charismatic Belfast nationalist, Joseph Devlin; and party and national unity were fundamental to his vision of politics in the wake of the Parnell Split. One of the central

Revue Française de Civilisation Britannique, XXIV-2 | 2019 
planks in the posthumous defence case for Redmond (mounted by Dillon) was that he had fought partition tooth and nail - and had left Ireland united at the time of his death in $1918 .^{24}$

Indeed, while Redmond and Carson were famously opposed on the national question, they both tentatively explored (as many do within the UK today) federalism (or explicitly shared sovereignty) as a means of bridging their political positions. For Carson federalism was a means of creating an Irish parliament within the overall context of a reformed union government of the United Kingdom. For Redmond, federalism was a means of redefining the government of the whole empire. But federalism also worked for Redmond within an Irish environment, allowing the possibility of the north enjoying a distinctive status but within an all-Ireland rather than a British context. Here again Redmond was simultaneously looking forward to later (often republican) thought on the shape of an allIreland state; but he may also have been looking back to the precedent of other European composite monarchies like Austria-Hungary, and to the Home Rule relationships (such as those enjoyed by Croatia) within the two halves of that state. In short, federalism whether in 1914 or now - offered a common vocabulary and a hope of bipartisanship which perhaps masked conceptually very different approaches and goals.

Linked with this, Redmond and Carson each looked beyond national borders to wider supranational and (in the case of Redmond) diasporic concerns. Redmond sought to balance the power of London using the devices of the empire and the Irish diaspora. Strikingly, Carson did not have the same vision of empire as did Redmond - nor did he have the same active and constructive engagement with colonial ministerial networks and communities. Ultimately, Carson talked the talk about empire; but it was Redmond who envisioned and practised it.

We know of course that Redmond's vision of Irish self-government was superseded by that of Sinn Féin and that he died 100 years ago, a disappointed man. We know, too, that Carson shifted gradually from an all-Ireland unionism to a six-county exclusionist or partitionist stance. But Carson's public acceptance of the role of patriarch of Northern Ireland (which flourished in the 1930s) concealed a profound bitterness about the condition of all of Ireland in the 1920s.

This was repeated in private communications: in 1918 Carson wrote privately that he had "already agreed to the exclusion of six counties, although I think that arrangement unstatesmanlike and a poor solution." Despite his standing as patriarch of Northern Ireland he wrote in 1922 that "I feel I am a citizen without nationality or anything to be loyal to." In 1928 he confided that he thought "there'd be more decency in a Republic than in this [Free State] humbug. In fact I'd rather see a republic." He claimed in private at this time that " looking back at politics, I think we made a great mistake in not accepting Mr Gladstone's first Home Rule bill." ${ }^{25}$

The difference between Carson and Redmond on partition was in the end essentially the difference between explicitly arguing and implicitly thinking in partitionist terms - or (alternatively) the difference between disliking and loathing partition.

\section{Conclusion}

After a century it is surely worth reuniting Redmond and Carson analytically. In reality neither could ever wholly be understood without recourse to the other. Nor can each be 
fully understood without some recourse to the shape and functioning of the multinational union state. Redmond's approach to a succession of fundamental issues - such as militancy and partition and the endorsement of the war effort - was at least in part influenced by Carson's actions and strategies. Carson's own actions in key areas were partly conditioned by a particular view of Irish nationalism and the ways in which successive union governments operated. Redmond had vision, but lacked passion; Carson lacked vision, but could provide the theatrical passion in spadeloads.

Redmond on the whole played by the parliamentary and political rule-book, including the opaque Parnellite rule-book; he became the key executor of the great man's highly fraught and ambiguous legacies. He sought for consistency and honour in his private and public dealings. Carson bent and broke rules and revelled in contradictions while all the while proclaiming his directness, simplicity and consistency. Yet he was at times the lawless lawyer; the disloyal loyalist; the all-Ireland partitionist. He bequeathed complex legacies to his compatriots in the North, including legacies of dangerous brinkmanship. ${ }^{26}$ He simultaneously embraced and owned his standing as a state-builder in Northern Ireland - while privately complaining at length about the new dispensations of the 1920s. Ireland for long has been a land of secret histories, of hybridity and liminality, where the reality of political experience has sometimes been buried, and often kept far apart from the ideal. The ideal has been a treasured vision of pristine political struggle: the reality has often involved day-to-day compromises with power, ambiguous family heritages and quotidian and understandable (if not very glamorous) struggles for survival and betterment. Edward Carson lived long enough to rewrite his own history, and thereby to mask the shifts and failures in his political life: he lived long enough to impose a form of consistency on a long and inconsistent career whose central themes were simultaneously the law and the breaking of the law.

It was John Redmond's tragedy that he all too clearly embodied compromise, ambiguity and struggle. But at the same time these complexities also reflected the reality of much individual and collective Irish historical experience. And herein lie both Redmond's authenticity and his importance for us all today.

\section{BIBLIOGRAPHY}

\section{Manuscript and archival sources}

Churchill College Cambridge, Winston Churchill Papers.

National Library of Scotland, F.S. Oliver Papers.

Public Record Office of Northern Ireland, H.M. Hyde Papers.

Trinity College Dublin, Dillon Papers. 


\section{Newspaper sources}

Freeman's Journal.

\section{Secondary sources}

Beller, Steven, Francis Joseph (Harlow, Longman, 1996).

Carson, Harry \& Louis Redmond-Howard, An Irishman's Home or the Crisis: a topical play on the Ulster question (London, Simpkin, Marshall Hamilton, Kent and Co. Ltd., 1914).

Cole, Laurence \& Daniel Unowsky (eds), The Limits of Loyalty: imperial symbolism, popular allegiances, and state patriotism in the late Habsburg monarchy (Oxford and New York, Berghahn Books, 2009).

Dunphy, Richard, The Making of Fianna Fáil Power in Ireland, 1923-48 (Oxford, Clarendon Press, 1995).

Fanning, Ronan Fatal Path: British government and Irish revolution (London, Faber \& Faber, 2013).

Gwynn, Stephen, John Redmond's Last Years (London, E. Arnold, 1919).

Hechter, Michael, Internal Colonialism: the Celtic fringe in British national development, 1536-1966

(London, Routledge \& Kegan Paul, 1975).

Hyde, H.M., Carson: the Life of Sir Edward Carson, Lord Carson of Duncairn (London, Heinemann, 1953).

Hoppen, K.Theodore, Governing Hibernia: British politicians and Ireland, 1800-1921 (Oxford, Oxford University Press, 2016).

Howe, Stephen, Ireland and Empire: colonial legacies in Irish history and culture (Oxford, Oxford University Press, 2000).

Jackson, Alvin ,The Ulster Party: Irish Unionists in the House of Commons, 1884-1911 (Oxford, Clarendon Press, 1989).

Jackson, Alvin, “Unionist myths, 1912-85”, Past \& Present, 136 (August 1992), pp. 164-85.

Jackson, Alvin, Home Rule: an Irish history, 1800-2000 (London, Weidenfeld \& Nicolson, 2003).

Jackson, Alvin, "Shamrock and Saltire: Irish Home Rule, Independence and the Scottish Referendum, 1914-2014" in Senia Paseta (ed.), Uncertain Futures: essays about the Irish past for Roy Foster (Oxford, Oxford University Press, 2016), pp. 257-69.

Jackson, Alvin, Judging Redmond and Carson: comparative Irish lives (Dublin, Royal Irish Academy, 2018).

Jászi, Oszkár, The Dissolution of the Habsburg monarchy (Chicago, University of Chicago Press, 1929). Judson, Pieter, Exclusive Revolutionaries: liberal politics, social experience and national identity in the Austrian empire, 1848-1914 (Ann Arbor, University of Michigan Press, 1996).

Judson, Pieter \& Marsha Rozenblit (eds), Constructing Nationalities in East Central Europe (New York and Oxford, Berghahn Books, 2004).

Judson, Pieter, Guardians of the Nation? Activists on the language frontiers of imperial Austria (Cambridge Mass., Harvard University Press, 2006).

Judson, Pieter, The Habsburg Empire: a new history (Cambridge, Mass., and London, Belknap Press of Harvard University Press, 2016). 
King, Jeremy, Budweisers into Czechs and Germans? A local history of Bohemian politics, 1848-1948

(Princeton, Princeton University Press, 2002).

Marjoribanks, Edward \& Ian Colvin, Life of Lord Carson (London, Gollancz,1932-6).

Meleady, Dermot, Redmond: the Parnellite (Cork, Cork University Press, 2008).

Nansen, Fridtjof Norway and the Union with Sweden (London, Macmillan \& Co., 1905).

Smith, Jeremy, "Federalism, Devolution and Partition: Sir Edward Carson and the Search for a Compromise on the third Home Rule Bill", Irish Historical Studies, 35, 140 (Nov. 2007), pp. 496-518.

Wheatley, Michael, “John Redmond and Federalism in 1910", Irish Historical Studies, 32, 127 (May 2001), pp. 343-364.

\section{NOTES}

1. For Carson and federalism see Jeremy Smith, "Federalism, Devolution and Partition: Sir Edward Carson and the Search for a Compromise on the third Home Rule Bill", Irish Historical Studies, 35, 140 (Nov. 2007), pp. 496-518; for Redmond and federalism see Michael Wheatley, "John Redmond and Federalism in 1910", Irish Historical Studies, 32, 127 (May 2001), pp. 343-64.

2. Harry Carson and Louis Redmond-Howard, An Irishman's Home or the Crisis: a topical play on the Ulster question (London, Simpkin, Marshall Hamilton, Kent and Co. Ltd., 1914).

3. Alvin Jackson, "Shamrock and Saltire: Irish Home Rule, Independence and the Scottish Referendum, 1914-2014" in Senia Paseta (ed.), Uncertain Futures: essays about the Irish past for Roy Foster (Oxford, Oxford University Press, 2016), pp. 257-69.

4. Ibid., p.259.

5. Dermot Meleady, Redmond: the Parnellite (Cork, Cork University Press, 2008), p. 25.

6. "Notes of a conversation with Mrs St George Robinson (sister of Lord Carson), supplemented by Lady Carson", 22 July 1950 in Public Record office of Northern Ireland, H.M. Hyde Papers, D.3084/H/3/9.

7. Anna Debenham to Hyde, 12 Nov 1951 in Hyde Papers, D.3084/H/2/91.

8. There is an extensive debate on Ireland's relationship with empire. For a starting point see Stephen Howe, Ireland and empire: colonial legacies in Irish history and culture (Oxford, Oxford University Press, 2000); see also Michael Hechter, Internal colonialism: the Celtic fringe in British national development, 1536-1966 (London, Routledge \& Kegan Paul, 1975).

9. K.Theodore Hoppen, Governing Hibernia: British politicians and Ireland, 1800-1921 (Oxford, Oxford University Press, 2016).

10. Steven Beller, Francis Joseph (Harlow, Longman, 1996), p. 161.

11. Quoted in Ronan Fanning, Fatal Path: British government and Irish revolution (London, Faber \& Faber, 2013), pp. 88-9.

12. See for example Redmond to Churchill, 4 Aug 1914 in Churchill College Cambridge, Winston Churchill Papers, CHAR 2/64/10.

13. Redmond to Dillon, 22 July 1908 in Trinity College Dublin, John Dillon Papers, 6748/377.

14. Edward Marjoribanks and Ian Colvin, Life of Lord Carson (London, Gollancz, 1932-6), iii, p. 27; Stephen Gwynn, John Redmond's last years (London, E. Arnold, 1919), p. 147.

15. See Oszkár Jászi, The Dissolution of the Habsburg monarchy (Chicago, University of Chicago Press, 1929); Pieter Judson, The Habsburg Empire: a new history (Cambridge, Mass., and London, Belknap Press of Harvard University Press, 2016).

16. For the Norwegian patriot, Fridtjof Nansen, the great antiquity of the monarchy in Norway meant that "fidelity to their Royal House has therefore always been particularly characteristic of 
the Norwegian peasantry": Fridtjof Nansen, Norway and the Union with Sweden (London, Macmillan \& Co., 1905), p. 5.

17. In terms of Habsburg historiography alone, see (for example) Laurence Cole and Daniel Unowsky (eds), The Limits of Loyalty: imperial symbolism, popular allegiances, and state patriotism in the late Habsburg monarchy (Oxford and New York, Berghahn Books, 2009); Pieter Judson, Exclusive Revolutionaries: liberal politics, social experience and national identity in the Austrian empire, 1848-1914 (Ann Arbor, University of Michigan Press, 1996); idem, Guardians of the Nation? Activists on the language frontiers of imperial Austria (Cambridge Mass., Harvard University Press, 2006); idem, The Habsburg empire; idem and Marsha Rozenblit (eds), Constructing Nationalities in East Central Europe (New York and Oxford, Berghahn Books, 2004); Jeremy King, Budweisers into Czechs and Germans? A local history of Bohemian politics, 1848-1948 (Princeton, Princeton University Press, 2002).

18. For the general theme see Richard Dunphy, The Making of Fianna Fáil Power in Ireland, 1923-48 (Oxford, Clarendon Press, 1995).

19. Meleady, Redmond: the Parnellite, p. 121

20. Redmond to O'Callaghan, 3 April 1908 (copy) in Dillon Papers, 6747/291

21. This is a key theme and argument of Alvin Jackson, The Ulster Party: Irish Unionists in the House of Commons, 1884-1911 (Oxford, Clarendon Press, 1989).

22. Jackson, Judging Redmond and Carson, p.162.

23. Alvin Jackson, Home Rule: an Irish history, 1800-2000 (London, Weidenfeld \& Nicolson, 2003), pp.124-5.

24. “Illustrious Leader': Mr John Dillon's Eloquent Tribute”, Freeman's Journal, 10 March 1924, in Dillon Papers, 6749/706.

25. Carson to Oliver, 5 Sept 1922 in National Library of Scotland, F.S. Oliver Papers, Ms.24856, f.157. See also H.M. Hyde, Carson: the life of Sir Edward Carson, Lord Carson of Duncairn (London, Heinemann, 1953), p.486, and Jackson, Judging Redmond and Carson, p.203.

26. Alvin Jackson, “Unionist myths, 1912-85”, Past \& Present, 136 (August 1992), pp. 164-85.

\section{ABSTRACTS}

John Redmond and Edward Carson together dominated the politics of Irish Home Rule and unionism between 1910 and 1918, and were major influences on Irish and British politics for an even longer period than this. Yet though contemporaries routinely viewed them together, and though they had a strong political and personal relationship, the hermeneutics of much modern Irish historical scholarship have precluded any systematic comparison. In fact, comparing Redmond and Carson provides important new illumination on the central themes of their careers, as well as on the political cultures of the multi-national union state within which they each operated.

John Redmond et Edward Carson ont tous les deux dominé les débats engendrés par la question du Home Rule et par l'unionisme entre 1910 et 1918, et ils ont eu une influence majeure sur la vie politique irlandaise et britannique pendant une période encore plus longue. Et pourtant, alors que leurs contemporains les associaient communément l'un avec l'autre et qu'ils entretenaient des relations personnelles et politiques fortes, l'herméneutique qui caractérise l'essentiel de l'historiographie de l'Irlande moderne a empêché toute comparaison systématique entre les deux hommes. En réalité, comparer Redmond et Carson permet de mettre en lumière de façon inédite 
ce qui constitua les thématiques centrales de leurs carrières et les cultures politiques de cet état né de l'Union de plusieurs nations dans lequel ils vécurent.

\section{INDEX}

Mots-clés: nationalisme, unionisme, Redmond, Carson, violence, fédéralisme

Keywords: nationalism, unionism, Redmond, Carson, violence, federalism

\section{AUTHOR}

\section{ALVIN JACKSON}

Alvin Jackson is Sir Richard Lodge Professor of History at the University of Edinburgh. He has written extensively on the history of modern Ireland and Britain, and is at present completing a comparative study of multi-national union states in the 19th and 20th centuries: his most recent published works include Judging Redmond and Carson (Royal Irish Academy, 2018), the Oxford Handbook of Modern Irish History (Oxford University Press, 2014) and The Two Unions: Ireland, Scotland and the Survival of the United Kingdom (Oxford University Press, 2012). He is an honorary member of the Royal Irish Academy and a member of the European Academy.

Alvin Jackson est titulaire de la chaire Sir Richard Lodge d'histoire à l'université d'Edimbourg. Après avoir publié de nombreux articles et ouvrages sur l'histoire moderne d'Irlande et de Grande-Bretagne, il termine une étude comparative des différents états multinationaux aux XIX et $\mathrm{XX}^{\mathrm{e}}$ siècles. Parmi ses ouvrages les plus récents, on mentionnera Judging Redmond and Carson (Royal Irish Academy, 2018), Oxford Handbook of Modern Irish History (Oxford University Press, 2014) et The Two Unions: Ireland, Scotland and the Survival of the United Kingdom (Oxford University Press, 2012). A. Jackson est membre honoraire de la Royal Irish Academy, et membre de l'Académie Européenne. 